\title{
Performa Fase Awal Produksi pada Ayam Ketarras dan Ayam Arab Betina
}

Desia Kaharuddin*, Kususiyah, Mulya Adi Saputra

Jurusan Peternakan, Fakultas Pertanian, Universitas Bengkulu

Jalan Raya W. R. Supratman, Kandang Limun, Bengkulu, 38371 A

*Korespondensi: desiakaharuddin6@gmail.com

Artikel ini diterima (received): 3 Januari 2020; dinyatakan disetujui (accepted): 2 Maret 2020; terbit (published): 15 Mei 2020. Artikel ini dipublikasi secara daring pada https://ejournal.unib.ac.id/index.php/buletin_pt

\begin{abstract}
ABSTRAK
Penelitian ini bertujuan untuk mengevaluasi performa fase awal produksi pada ayam Ketarras dan ayam Arab betina. Penelitian terdiri 2 perlakuan dan 25 ulangan. Faktor jenis ayam digunakan sebagai perlakuan, yaitu : P1 = ayam Ketarras betina dan P2 = ayam Arab betina. Setiap ulangan menggunakan 1 ekor ayam, yang ditempatkan pada kandang batteray individu. Hasil penelitian menunjukkan bahwa rataan umur dewasa kelamin ayam Ketarras lebih cepat dibandingkan dengan umur dewasa kelamin ayam Arab. Berat dewasa kelamin ayam Ketarras dan ayam Arab berbeda tidak nyata. Rataan berat dewasa kelamin ayam Ketarras lebih ringan dari berat dewasa kelamin ayam Arab. Rataan berat telur pertama ayam Ketarras dan ayam Arab nyata lebih tinggi. Konsumsi ransum kumulatif ayam Ketarras nyata lebih tinggi dari Arab. Rataan produksi telur selama penelitian ayam Ketarras nyata lebih tinggi dari ayam Arab. Rataan berat telur kumulatif pada ayam Ketarras nyata lebih tinggi dari ayam Arab berbeda nyata lebih tinggi. Berat telur pada ayam Ketarras lebih tinggi dibandingkan. Nilai konversi ransum awal pada masing-masing jenis ayam relatif lebih tinggi, untuk selanjutnya konversi ransum cenderung menurun diakhir penelitian ayam Ketarras dan ayam Arab. Warna kerabang telur ayam Ketarras 92,65\% berwarna putih kecoklatan. Penelitian ini dapat disimpulkan bahwa dewasa kelamin ayam Ketarras lebih cepat, dengan berat dewasa kelamin lebih ringan, berat telur pertama lebih berat, konsumsi ransum tidak berbeda nyata, produksi telur lebih tinggi serta konversi ransum lebih rendah dibandingkan ayam Arab, kerabang telur ayam Ketarras 92,65\% berwarna putih kecoklatan.
\end{abstract}

Kata kunci: Performans, Produksi, ayam Ketarras, ayam Arab.

\section{PENDAHULUAN}

Ayam Ketarras merupakan hasil persilangan ayam Arab dengan ayam Ras dengan komposisi genetic 75\% ayam Arab dan $25 \%$ ayam Ras melalui persilangan ayam Arras betina dengan ayam Arab jantan. Ayam Arras adalah hasil persilangan ayam Arab jantan dengan ayam Ras petelur coklat. Persilangan antara ayam Arab dan ayam Ras diharapkan dapat memunculkan efek komplementer sehingga telurnya berwarna putih kecoklatan seperti telur ayam Kampung. Hal ini dilakukan dalam upaya memfasilitasi penggemar telur ayam Kampung yang tidak setuju telur ayam Arab digunakan sebagai pengganti telur ayam Kampung karena warna kulit telurnya yang putih. Di pasar banyak pedagang menjual telur ayam Arab untuk memenuhi permintaan konsumen akan telur ayam Kampung karena produksi ayam Kampung masih rendah.

Pertimbangan menggunakan ayam Arab dalam persilangan adalah karena karakteristik telur ayam Arab kecuali warnanya menyerupai telur ayam Kampung disamping produksinya yang tinggi $190-250$ butir/tahun (Nataamijaya et al., 2003) sedangkan dari ayam Ras selain produksinya yang tinggi diharapkan memberi pengaruh pada warna kerabang telur.

Ambarwarti (2016) melaporkan bahwa ayam Arras dewasa kelamin pada umur 122 hari dengan rataan berat dewasa kelamin 1156 g serta berat telur pertama adalah $\pm 29 \mathrm{~g}$ 
dengan warna kerabang kecoklatan lebih mendekati warna telur ayam Ras. Arianto (2017), melaporkan bahwa rataan produksi telur umur 20 - 40 minggu pada ayam Arras lebih tinggi ayam Arab adalah $\pm 74,00 \%$ dan \pm $55,31 \%$ dengan warna kerabang telur ayam Arras kecoklatan. Arianto (2017) juga melaporkan rataan berat telur ayam Arras 45,66 g sedangkan rataan berat telur ayam Arab 33,88 g.

Berdasarkan laporan dan hasil penelitian di atas ayam Arras disilangkan kembali dengan ayam Arab yang diberi nama Ketarras dengan harapan muncul efek komplementer untuk sifat karakter ukuran telur dan warna kerabang telur.

Penelitian bertujuan untuk mengevaluasi performa fase awal produksi pada ayam Ketarras dan ayam Arab betina.

\section{MATERI DAN METODE}

\section{Persiapan kandang}

Kandang yang digunakan pada penelitian ini adalah kandang batteray individu sebanyak 50 petak, setiap unitnya berukuran panjang 50 $\mathrm{cm}$, lebar $23 \mathrm{~cm}$ dan tinggi $50 \mathrm{~cm}$. Kandang batteray dilengkapi dengan tempat minum dan tempat pakan.

Persiapan kandang sebelum dilaksanakan penelitian adalah sanitasi kandang, pembersihan kandang dari semua kotoran, membersihkan tempat pakan dan minum, menyiapkan tempat telur/karpet telur. Satu kandang batteray berisi satu ekor ayam.

\section{Pemeliharaan ayam}

Penelitian ini menggunakan ayam Ketarras betina dan ayam Arab betina umur 20 minggu, masing-masing jenis ayam dibutuhkan 25 ekor yang dipelihara dalam kandang batteray individu..
Ransum diberikan dua kali sehari yaitu pada pagi hari pukul 07.00 dan sore hari pukul 16.00 WIB. Ransum diberikan sesuai jumlah dan konsumsi pakan yang terdapat pada Tabel 3. ditambah $10 \%$ sebagai cadangan pakan. Air minum diberikan ad libitum. Pemberian ransum harus diberikan setiap hari sesuai dengan kebutuhan ayam, baik secara kuantitatif maupun kualitatifnya (Fadilah, 2004).

Bahan penyusun ransum yang digunakan dalam penelitian ini adalah dedak halus, jagung giling, dan konsentrat layer kusus (KLK). Nutrisi yang diberikan mengacu pada kebutuhan ransum ayam petelur pada fase produksi yaitu dengan Protein Kasar $17 \%$ dan Energi Metabolik 2850 kkal/kg (NRC,1994).

Kandungan nutrisi bahan penyusun ransum, formulasi ransum penelitian dan kandungan nutrisi ransum disajikan pada Tabel 1.

\section{Rancangan penelitian}

Penelitian ini menggunakan 2 perlakuan dan 25 ulangan. Faktor jenis ayam digunakan sebagai perlakuan, yaitu : PO = ayam Ketarras betina dan P1 = ayam Arab betina. Setiap ulangan menggunakan 1 ekor ayam, sehingga masing - masing jenis ayam dibutuhkan 25 ekor ayam yang ditempatkan pada kandang batteray individu.

Variabel yang diamati meliputi umur dewasa kelamin, berat dewasa kelamin, berat telur pertama, konsumsi ransum, berat telur, produksi telur, konversi ransum dan warna kerabang telur.

\section{Analisis data}

Data berat dewasa kelamin, umur dewasa kelamin, berat telur, konsumsi ransum, produksi telur, dianalisis menggunakan uji $\mathrm{t}$ dengan kepercayaan 95\% (Astuti, 2007).

Tabel 1. Formulasi ransum dan kandungan nutrisi ransum pada fase awal produksi.

\begin{tabular}{llllllll}
\hline Bahan & $\begin{array}{l}\text { Proporsi } \\
\text { Penyusun }\end{array}$ & $\begin{array}{l}\text { PK } \\
(\%)\end{array}$ & $\begin{array}{l}\text { ME } \\
(\mathrm{kkal} / \mathrm{kg})\end{array}$ & $\begin{array}{l}\text { SK } \\
(\%)\end{array}$ & $\begin{array}{l}\text { LK } \\
(\%)\end{array}$ & $\begin{array}{l}\text { Ca } \\
(\%)\end{array}$ & $\begin{array}{l}\text { P } \\
(\%)\end{array}$ \\
\hline Dedak & 32,00 & 3,52 & 787,20 & 3,84 & 3,13 & 0,00 & 0,42 \\
Jagung Giling & 37,00 & 3,29 & 1228,77 & 0,93 & 1,10 & 0,01 & 0,09 \\
KLK & 31,00 & 10,23 & 837,00 & 2,17 & 1,97 & 3,41 & 0,40 \\
Total & 100,00 & 17,04 & 2852,97 & 6,20 & 6,20 & 3,42 & 0,90 \\
\hline
\end{tabular}


Tabel 2. Rataan umur dewasa kelamin, berat dewasa kelamin, berat telur pertama.

\begin{tabular}{|c|c|c|c|c|c|c|}
\hline Perlakuan & $\begin{array}{l}\text { Umur } \\
\text { Kelamin }\end{array}$ & $\begin{array}{c}\text { Dewasa } \\
\text { (hari) }\end{array}$ & $\begin{array}{l}\text { Berat } \\
\text { Kelamin } \\
\text { (gram) }\end{array}$ & Dewasa & $\begin{array}{l}\text { Berat } \\
\text { Pertama } \\
\text { (gram) }\end{array}$ & Telur \\
\hline P0 (Ayam Ketarras) & 135 & & 1308,48 & & 34,24 & \\
\hline P1 (Ayam Arab) & 147 & & 1361,76 & & 30,52 & \\
\hline Keterangan & & & ns & & $*$ & \\
\hline
\end{tabular}

Keterangan $:$ ns = berbeda tidak nyata ), ${ }^{*}=$ berbeda nyata

\section{HASIL DAN PEMBAHASAN \\ Umur dewasa kelamin, berat dewasa kelamin, berat telur pertama}

Umur dewasa kelamin, berat dewasa kelamin, dan berat telur pertama ayam Ketarras dan ayam Arab disajikan pada Tabel 2.

Seekor ayam diasumsikan telah mencapai dewasa kelamin jika ayam tersebut telah bertelur untuk pertama kalinya. Tabel 4 menunjukkan bahwa umur dewasa kelamin ayam Ketarras berkisar 121-161 hari (Lampiran 1) dengan rataan 135 hari, lebih cepat dibandingkan dengan umur dewasa kelamin ayam Arab yang berkisar antara 129-173 hari (Lampiran 1) dengan rataan 147 hari. Rataan tersebut menunjukkan bahwa dewasa kelamin ayam Ketaras lebih cepat 12 hari dibandingkan dengan ayam Arab.

Perbedaan umur dewasa kelamin antara kedua jenis ayam percobaan ini diduga disebabkan oleh perbedaan genetik dari kedua jenis ayam. Ayam Ketarras mengandung genetik dari ayam Arras (50\% Arab dan 50\% Ras petelur), sehingga ayam Ketarras mengandung $25 \%$ genetik ayam Ras petelur dan $75 \%$ ayam Arab. Indra et al. (2013), menyatakan bahwa umur dewasa kelamin dipengaruhi oleh strain. Sonhaji (2007) menyatakan bahwa ayam Arab mencapai dewasa kelamin umur 135-165 hari.

Menurut Ambarwati (2016) umur dewasa kelamin ayam Arras berkisar 112-138 hari dengan rataan 134 hari, umur dewasa kelamin ayam Arras lebih cepat 12 hari dibandingkan ayam Arab. Hal tersebut menunjukkan bahwa rataan umur dewasa kelamin ayam Ketarras satu hari lebih lama dibandingkan dengan rataan dewasa kelamin ayam Arras sebagai tetuanya, akan tetapi jauh lebih cepat dibandingkan dengan ayam Arab.

Berat dewasa kelamin ayam Ketarras dan ayam Arab diperoleh berdasarkan hasil penimbangan ayam pada saat pertama kali bertelur. Berat dewasa kelamin ayam Ketarras dan ayam Arab disajikan pada Lampiran 2. Hasil uji t menunjukkan bahwa berat dewasa kelamin ayam Ketarras dan ayam Arab berbeda tidak nyata (t hitung < t tabel). Berat dewasa kelamin ayam Ketarras (1308,48 gram) lebih ringan dibandingkan dengan berat dewasa kelamin ayam Arab (1361,76 gram). Terlihat bahwa, meskipun berbeda tidak nyata capaian berat dewasa kelamin ayam Ketarras lebih ringan dibandingkan dengan berat dewasa kelamin ayam Arab. Diduga hal ini disebabkan karena ayam Ketarras lebih cepat mencapai dewasa kelamin dibandingkan dengan ayam Arab. Menurut Ambarwati (2016) berat dewasa kelamin ayam Arras yaitu 1156 gram dan ayam Arab 1076 gram.

Menurut Fadilah dan Fatkhuroji (2013), ayam Ras petelur akan mencapai dewasa kelamin dengan berat 1550 g. Ahmad (2017) pada penelitian sebelumnya menjelaskan bahwa berat badan ayam Ketarras pada umur 20 minggu lebih tinggi dibandingkan dengan berat badan ayam Arab, namun berat dewasa kelamin ayam Ketarras lebih rendah dibanding dengan ayam Arab, hal ini disebabkan karena umur dewasa kelamin ayam Ketarras lebih cepat dibandingkan ayam Arab.

Berdasarkan penjelasan tersebut terlihat bahwa berat dewasa kelamin ayam Ketarras lebih ringan dibandingkan dengan berat dewasa kelamin ayam Arab dan juga lebih ringan dibandingkan dengan berat dewasa kelamin ayam Ras petelur.

Uji $\mathrm{t}$ menunjukkan bahwa berat telur pertama ayam Ketarras dan ayam Arab berbeda nyata (t hitung $>\mathrm{t}$ tabel). Berat telur pertama ayam Ketarras berkisar antara 28-40 gram dengan rataan 34,24 gram lebih berat dibandingkan dengan berat telur pertama ayam Arab yang berkisar antara 25-40 gram dengan rataan 30,52 gram (Lampiran 2). Lebih tingginya rataan berat telur pertama ayam Ketarras dibandingkan dengan rataan berat 
telur pertama ayam Arab diduga disebabkan oleh perbedaan genetik dari kedua jenis ayam. Ayam Ketarras mengandung 25\% genetik ayam Ras petelur dan $75 \%$ ayam Arab. Menurut Ambarwati (2016) rataan berat telur pertama ayam Arras 29 gram/butir lebih berat dibandingkan dengan rataan berat telur pertama ayam Arab 26 gram/butir.

Dapat disimpulkan bahwa rataan berat telur pertama ayam Ketarras lebih berat jika dibandingkan dengan rataan berat telur pertama ayam Arras dan ayam Arab. hal ini disebabkan karena setiap ayam mempunyai genetik yang berbeda. Indra et al. (2013), menyatakan bahwa berat telur dipengaruhi oleh strain.

\section{Konsumsi ransum}

Konsumsi ransum mingguan merupakan jumlah ransum yang disediakan pada awal minggu dikurangi dengan sisa ransum pada akhir minggu. Konsumsi ransum mingguan disajikan pada Tabel 3.

Hasil uji t menunjukkan bahwa konsumsi ransum ayam Ketarras dan ayam Arab pada minggu ke 17,18,19,21,23,24,26 dan 28 berbeda tidak nyata (t hitung $<\mathrm{t}$ tabel). Namun pada minggu ke 20,22,25, dan 27 konsumsi ransum ayam Ketarras berbeda nyata (t hitung >t tabel) dibandingkan dengan ayam Arab. Hal ini menunjukkan bahwa perbedaan genetik ayam Ketarras dan ayam Arab mempengaruhi konsumsi ransum umur 17-28 minggu secara nyata. Bila dibandingkan dengan tetuanya konsumsi ransum ayam Arras $(2960,92)$ pada fase starter tidak berbeda nyata dibanding konsumsi ransum ayam Arab $(2975,58)$. (Nur 2016). Konsumsi ransum ayam Arras pada minggu ke 21-28 berkisar (531,5-671,7 g/ekor/minggu) dengan rataan 661,14 g/ekor/minggu dan ayam Arab ( 526,6-642,7 g/ekor/minggu) dengan rataan 586,66 g/ekor/minggu (Arianto. 2017). Sedangkan rataan konsumsi mingguan ayam Ketarras pada umur yang sama berkisar 514,36-716,4 g/ekor/minggu dengan rataan 661,14 g/ekor/minggu dan ayam Arab 513,72-683,64 g/ekor/minggu dengan rataan 635,68 g/ekor/minggu.

Menurut Indra et al. (2013), salah satu faktor yang mempengaruhi konsumsi ransum adalah genetik. Priono (2003), menyatakan konsumsi ransum dipengaruhi oleh beberapa faktor yaitu besar dan bangsa ayam, temperatur lingkungan, dan tahap produksi.

Konsumsi ransum kumulatif ayam Ketarras dan ayam Arab disajikan pada Tabel 4. Hasil uji t konsumsi ransum kumulatif ayam Ketarras dan ayam Arab pada umur 16-17 sampai 16-26 berbeda tidak nyata (t hitung $<\mathrm{t}$ tabel). Sedangkan pada umur 16-27 sampai 1628 konsumsi ransum ayam Ketarras berbeda nyata lebih rendah dibandingkan ayam Arab. Hal ini menunjukkan bahwa faktor perbedaan genetik ayam Ketarras (25\% Ras dan 75\% Arab) dengan ayam Arab (100\% Arab) berpengaruh terhadap konsumsi ransum.

Tabel 3. Rataan konsumsi ransum ayam Ketarras dan ayam Arab.

\begin{tabular}{|c|c|c|c|}
\hline Minggu Ke & PO (Ayam Ketarras) & P1 (Ayam Arab) & Keterangan \\
\hline \multicolumn{4}{|c|}{...............gram/ekor/minggu................ } \\
\hline 17 & $438,88 \pm 27,68$ & $444,16 \pm 21,90$ & ns \\
\hline 18 & $453,96 \pm 31,86$ & $454,56 \pm 21,38$ & ns \\
\hline 19 & $455,20 \pm 28,14$ & $455,72 \pm 27,39$ & ns \\
\hline 20 & $512,84 \pm 28,12$ & $484,68 \pm 24,90$ & $*$ \\
\hline 21 & $514,36 \pm 27,42$ & $513,72 \pm 30,91$ & ns \\
\hline 22 & $716,40 \pm 38,91$ & $666,92 \pm 46,10$ & $*$ \\
\hline 23 & $660,36 \pm 55,03$ & $683,64 \pm 40,49$ & ns \\
\hline 24 & $668,24 \pm 54,68$ & $655,72 \pm 53,19$ & ns \\
\hline 25 & $675,52 \pm 46,56$ & $640,92 \pm 60,26$ & $*$ \\
\hline 26 & $674,64 \pm 57,47$ & $646,48 \pm 60,00$ & ns \\
\hline 27 & $692,48 \pm 46,78$ & $623,36 \pm 75,09$ & $*$ \\
\hline 28 & $687,12 \pm 48,55$ & $656,68 \pm 56,60$ & ns \\
\hline
\end{tabular}

Keterangan :ns = berbeda tidak nyata ), * = berbeda nyata 
Tabel 4. Rataan konsumsi ransum kumulatif ayam Ketarras dan ayam Arab.

\begin{tabular}{llll}
\hline Umur (minggu) & P0 (Ayam Ketarras) & P1 (Ayam Arab) & Keterangan \\
\hline$\ldots \ldots \ldots \ldots . .$. gram/ekor............ & & \\
$16-17$ & $438,88 \pm 27,68$ & $444,16 \pm 21,90$ & $\mathrm{~ns}$ \\
$16-18$ & $892,84 \pm 44,29$ & $898,72 \pm 33,55$ & $\mathrm{~ns}$ \\
$16-19$ & $1348,04 \pm 64,22$ & $1354,44 \pm 50,09$ & $\mathrm{~ns}$ \\
$16-20$ & $1860,88 \pm 87,27$ & $1839,12 \pm 61,62$ & $\mathrm{~ns}$ \\
$16-21$ & $2375,24 \pm 111,60$ & $2352,84 \pm 82,26$ & $\mathrm{~ns}$ \\
$16-22$ & $3091,64 \pm 134,83$ & $3019,76 \pm 113,55$ & $\mathrm{~ns}$ \\
$16-23$ & $3752,00 \pm 165,64$ & $3703,40 \pm 145,46$ & $\mathrm{~ns}$ \\
$16-24$ & $4420,24 \pm 196,95$ & $4359,12 \pm 190,78$ & $\mathrm{~ns}$ \\
$16-25$ & $5095,76 \pm 232,59$ & $5000,04 \pm 231,50$ & $\mathrm{~ns}$ \\
$16-26$ & $5770,40 \pm 271,12$ & $5646,52 \pm 277,67$ & $\mathrm{~ns}$ \\
$16-27$ & $6462,88 \pm 303,35$ & $6269,88 \pm 328,15$ & $*$ \\
$16-28$ & $7150,00 \pm 332,51$ & $6926,56 \pm 373,80$ & $*$ \\
\hline
\end{tabular}

Keterangan :ns = berbeda tidak nyata ), * = berbeda nyata

Tabel 4 menjelaskan bahwa konsumsi ransum kumulatif ayam Ketarras umur 16-28 minggu (7150 gram/ekor) sedikit lebih tinggi dibandingkan ayam arab (6927 gram/ekor), akan tetapi secara keseluruhan jumlah konsumsi ransum antara kedua jenis ayam berbeda nyata.

\section{Produksi telur}

Produksi telur mingguan ayam Ketarras dan ayam Arab sejak minggu ke 17-28 disajikan pada Tabel 5.

Ayam Ketarras pada penelitian ini mulai ada yang bertelur pada minggu ke 17 sedangkan ayam Arab pada minggu ke 18. Produksi telur umur 17 - 19 minggu relatif masih rendah karena masih banyak ayam yang belum dewasa kelamin sehingga uji t dianalisis mulai umur 20 minggu. Hasil uji t menunjukkan bahwa rataan produksi telur minggu ke 20, 21 dan 23 ayam Ketarras berbeda nyata lebih tinggi (t hitung > t tabel) dibandingkan ayam Arab, sedangkan pada minggu ke 22 dan 25-28 rataan berbeda tidak nyata ( $\mathrm{t}$ hitung $<\mathrm{t}$ tabel). Terjadinya perbedaan produksi telur ayam Ketarras dan ayam Arab pada umur 20-21 minggu ini disebabkan karena ayam Ketarras lebih dulu dewasa kelamin sehingga pada umur tersebut sudah terjadi peningkatan produksi sementara itu ayam Arab baru mulai berproduksi. Selanjutnya tidak terdapatnya perbedaan produksi pada umur 25-28 minggu karena pada umur tersebut ayam Arab telah meningkat produksinya.

Ayam Ketarras mampu berproduksi lebih tinggi dibandingkan ayam Arab, hal ini terlihat dari persentase produksi telur per minggunya, capaian produksi telur tertinggi ayam Ketarras mencapai 76,00\% pada umur 24 minggu sedangkan ayam Arab mencapai $74,29 \%$ pada umur ke 26 minggu. Arianto (2017) menyatakan bahwa capaian produksi telur ayam Arras mencapai 81,95 \% sedangkan ayam Arab $72,86 \%$. Terlihat bahwa capaian produksi ayam Ketarras masih lebih rendah dibandingkan tetuanya (ayam Arras) tetapi masih lebih tinggi jika dibandingkan dengan ayam Arab. Gambar 2 memperlihatkan grafik produksi telur ayam Ketarras dan ayam Arab.

Arianto (2017) menyatakan bahwa ayam Arras mencapai puncak produksi pada umur 24 minggu dan ayam Arab umur 27 minggu dan pada umur 26-30 produksi ayam Arras dan arab relatif sama. Silversides et al. (2006), dan Singh et al. (2009), menyatakan bahwa pencapaian produksi telur yang optimal dipengaruhi oleh faktor genetik (strain).

Produksi telur kumulatif ayam Ketarras dan ayam Arab disajikan pada Tabel 6. Secara kumulatif jumlah telur ayam Ketarras dan ayam Arab pada umur 16-20 sampai $16-28$ minggu berbeda nyata ( $\mathrm{t}$ hitung $>\mathrm{t}$ tabel). Jumlah produksi telur kumulatif ayam Ketarras nyata lebih tinggi dibandingkan ayam Arab. Jumlah telur kumulatif ayam Ketarras pada umur 16-28 minggu mencapai 40,56 butir/ekor sedangkan ayam Arab mencapai 33,00 butir/ekor. Terlihat bahwa rataan produksi telur ayam Ketarras lebih tinggi dibandingkan dengan rataan produksi ayam Arab. Hal ini menunjukkan bahwa perbedaan genetik ayam Ketarras yang mempunyai genetik ayam Ras petelur dapat meningkatkan produksi telur dibandingkan ayam Arab. 
Tabel 5. Rataan produksi telur (butir) ayam Ketarras dan ayam Arab.

\begin{tabular}{|c|c|c|c|c|c|}
\hline \multirow[b]{2}{*}{ Minggu Ke } & \multicolumn{2}{|c|}{ P0 (Ayam Ketarras) } & \multicolumn{2}{|c|}{ P1 (Ayam Arab) } & \multirow[b]{2}{*}{ Keterangan } \\
\hline & $\begin{array}{l}\text { Butir } \\
\text { Perminggu }\end{array}$ & $\begin{array}{l}\text { Persen } \\
(\%)\end{array}$ & $\begin{array}{l}\text { Butir } \\
\text { Perminggu }\end{array}$ & $\begin{array}{l}\text { Persen } \\
(\%)\end{array}$ & \\
\hline 17 & $0,24 \pm 0,58$ & 3,43 & - & - & - \\
\hline 18 & $0,96 \pm 0,63$ & 13,71 & $0,04 \pm 0,00$ & 0,57 & - \\
\hline 19 & $1,60 \pm 0,79$ & 22,86 & $0,28 \pm 0,41$ & 4,00 & - \\
\hline 20 & $2,00^{a} \pm 0,86$ & 28,57 & $0,76^{b} \pm 0,63$ & 10,86 & $*$ \\
\hline 21 & $2,76^{a} \pm 1,45$ & 39,43 & $1,40^{b} \pm 0,46$ & 20,00 & $*$ \\
\hline 22 & $3,48 \pm 1,90$ & 49,71 & $2,52 \pm 1,32$ & 36,00 & ns \\
\hline 23 & $4,60^{a} \pm 1,35$ & 65,71 & $3,44^{b} \pm 1,32$ & 49,14 & $*$ \\
\hline 24 & $5,32 \pm 1,10$ & 76,00 & $4,32 \pm 1,69$ & 61,71 & ns \\
\hline 25 & $5,04 \pm 1,37$ & 72,00 & $5,04 \pm 1,15$ & 72,00 & ns \\
\hline 26 & $4,88 \pm 1,35$ & 69,71 & $5,20 \pm 0,83$ & 74,29 & ns \\
\hline 27 & $4,76 \pm 0,78$ & 68,00 & $5,08 \pm 0,95$ & 72,57 & ns \\
\hline 28 & $4,92 \pm 1,12$ & 70,29 & $4,92 \pm 1,26$ & 70,29 & ns \\
\hline
\end{tabular}

Keterangan :ns = berbeda tidak nyata ), * = berbeda nyata

Tabel 6. Rataan jumlah telur (butir).

\begin{tabular}{llll}
\hline Umur & P0 (Ayam Ketarras) & P1 (Ayam Arab) & Keterangan \\
\hline$\ldots \ldots \ldots \ldots$ butir/ekor............... & & \\
$16-17$ & $0,24 \pm 0,58$ & - & - \\
$16-18$ & $1,20 \pm 1,13$ & $0,04 \pm 0,00$ & - \\
$16-19$ & $2,80 \pm 1,93$ & $0,32 \pm 0,82$ & $*$ \\
$16-20$ & $4,80^{\mathrm{a}} \pm 2,51$ & $1,08^{\mathrm{b}} \pm 0,94$ & $*$ \\
$16-21$ & $7,56^{\mathrm{a}} \pm 3,94$ & $2,48^{\mathrm{b}} \pm 1,12$ & $*$ \\
$16-22$ & $11,04^{\mathrm{a}} \pm 6,16$ & $5,00^{\mathrm{b}} \pm 2,02$ & $*$ \\
$16-23$ & $15,64^{\mathrm{a}} \pm 7,36$ & $8,44^{\mathrm{b}} \pm 3,28$ & $*$ \\
$16-24$ & $20,96^{\mathrm{a}} \pm 8,30$ & $12,76^{\mathrm{b}} \pm 5,22$ & $*$ \\
$16-25$ & $26,00^{\mathrm{a}} \pm 8,81$ & $17,80^{\mathrm{b}} \pm 6,10$ & $*$ \\
$16-26$ & $30,88^{\mathrm{a}} \pm 9,14$ & $23,00^{\mathrm{b}} \pm 6,84$ & $*$ \\
$16-27$ & $35,64^{\mathrm{a}} \pm 9,91$ & $28,08^{\mathrm{b}} \pm 7,62$ & $*$ \\
$16-28$ & $40,56^{\mathrm{a}} \pm 10,57$ & $33,00^{\mathrm{b}} \pm 8,32$ & $*$ \\
\hline
\end{tabular}

Keterangan :ns = berbeda tidak nyata ), * = berbeda nyata

Susilorini, et al. (2008), mengemukakan bahwa ayam Ras petelur adalah ayam yang sangat efisien menghasilkan telur. Efisiensi produksi telur yang optimal dipengaruhi oleh faktor genetik (strain) dan pencapaian kematangan seksual yang tepat (Cankaya, et al., 2008). Tercapainya kematangan seksual yang lebih cepat umumnya akan mempercepat puncak produksi Silversides, et al., 2006), Singh et al., 2009).

Pebedaan genetik antara ayam Ketarras dengan ayam Arab diduga berpengaruh terhadap produksi telur. Selain genetik hal lain yang berpengaruh terhadap produksi telur adalah umur dewasa kelamin. Ayam Ketarras mencapai dewasa kelamin lebih cepat dibandingkan dengan ayam Arab.

\section{Produksi berat telur}

Hasil uji $\mathrm{t}$ menunjukkan bahwa berat telur ayam Ketarras berbeda nyata lebih tinggi sejak minggu ke 20 sampai minggu ke 24, sedangkan pada minggu ke 25-28 berat telur ayam Ketarras berbeda tidak nyata dengan ayam Arab. Lebih tingginya produksi telur ayam Ketarras dibandingkan ayam Arab diduga disebabkan karena dewasa kelamin ayam Ketarras lebih cepat dibandingkan ayam Arab. menurut Hudson, et al, (2001) produksi telur juga berkaitan erat dengan pencapaian kematangan seksual yang tepat.

Produksi berat telur mingguan ayam Ketarras dan ayam Arab minggu ke 17-28 disajikan pada Tabel 7. 
Dapat dilihat pada tabel 8. bahwa berat perbutir telur ayam Ketarras berkisar antara 33-43,54 gram/butir dengan rataan 38,67 gram/butir lebih berat dibandingkan dengan berat perbutir telur ayam Arab yang berkisar antara 27-38,32 gram/butir dengan rataan 33,63 gram/butir.

Arianto (2017) menyatakan bahwa rataan berat perbutir telur ayam Arras umur 21-40 minggu (45,66 gram/butir) lebih tinggi dibandingkan rataan berat perbutir telur ayam Arab umur 21-40 (33,88 gram/butir). Hal ini menunjukkan bahwa jika dibandingkan dengan tetuanya (ayam Arras), berat perbutir ayam telur Kettaras lebih rendah dibandingkan dengan telur ayam Arras akan tetapi lebih berat dibandingkan dengan telur ayam Arab.

Rataan produksi telur kumulatif ayam Ketarras dan ayam Arab disajikan pada Tabel 9. Hasil uji t berat telur kumulatif ayam Ketarras dan ayam Arab berbeda nyata ( $\mathrm{t}$ hitung $>\mathrm{t}$ tabel). Jumlah kumulatif berat telur ayam Ketarras lebih tinggi dibandingkan ayam Arab. Jumlah produksi telur ayam Ketarras pada umur 16-28 mencapai 1643,28 gram sedangkan ayam Arab mencapai 1182,32 gram. Hal ini menunjukkan bahwa perbedaan genetik antara ayam Ketarras dan ayam Arab berpengaruh terhadap produksi telur.

Tabel 7. Rataan produksi masa telur ayam Ketarras dan ayam Arab.

\begin{tabular}{|c|c|c|c|}
\hline Minggu Ke & P0 (Ayam Ketarras) & P1 (Ayam Arab) & Keterangan \\
\hline \multicolumn{4}{|c|}{...............gram/ekor/minggu................ } \\
\hline 17 & $7,80 \pm 17,19$ & - & - \\
\hline 18 & $31,32 \pm 19,96$ & $1,08 \pm 0,00$ & - \\
\hline 19 & $56,08 \pm 27,81$ & $7,72 \pm 13,70$ & - \\
\hline 20 & $74,16^{a} \pm 35,09$ & $22,68^{b} \pm 20,42$ & $*$ \\
\hline 21 & $103,96^{a} \pm 57,19$ & $44,76^{b} \pm 15,03$ & $*$ \\
\hline 22 & $139,60^{\mathrm{a}} \pm 82,57$ & $86,16^{b} \pm 42,34$ & $*$ \\
\hline 23 & $184,56^{a} \pm 59,24$ & $120,32^{b} \pm 45,98$ & $*$ \\
\hline 24 & $216,64^{a} \pm 52,92$ & $153,92^{b} \pm 58,10$ & $*$ \\
\hline 25 & $208,32 \pm 59,74$ & $181,60 \pm 48,11$ & ns \\
\hline 26 & $203,16 \pm 58,81$ & $190,68 \pm 35,58$ & ns \\
\hline 27 & $203,36 \pm 37,27$ & $191,48 \pm 37,92$ & ns \\
\hline 28 & $214,32 \pm 51,21$ & $186,92 \pm 44,97$ & ns \\
\hline
\end{tabular}

Keterangan :ns = berbeda tidak nyata ), * = berbeda nyata

Tabel 8. Berat perbutir telur

\begin{tabular}{lll}
\hline \multirow{2}{*}{ Minggu Ke } & Berat Perbutir Telur & \\
\cline { 2 - 3 } & P0 (Ayam Ketarras) & \\
17 & $\ldots \ldots \ldots . .$. gram/butir/minggu......... & \\
18 & 33,00 & 27,00 \\
19 & 33,03 & 27,17 \\
20 & 35,25 & 29,54 \\
21 & 36,69 & 31,86 \\
22 & 37,32 & 34,65 \\
23 & 39,41 & 35,08 \\
24 & 39,88 & 36,15 \\
25 & 40,55 & 35,79 \\
26 & 41,29 & 36,60 \\
27 & 41,43 & 37,72 \\
28 & 42,68 & 38,32 \\
\hline Rataan & 43,54 & 33,63 \\
\hline
\end{tabular}


Tabel 9. Rataan produksi masa t telur kumulatif ayam Ketarras dan ayam Arab.

\begin{tabular}{llll}
\hline Umur & P0 (Ayam Ketarras) & P1 (Ayam Arab) & Keterangan \\
\hline & $\ldots \ldots \ldots \ldots . .$. gram/ekor............... & \\
$16-17$ & $7,80 \pm 17,19$ & - & - \\
$16-18$ & $39,12 \pm 36,11$ & $1,08 \pm 0,00$ & - \\
$16-19$ & $95,20 \pm 62,21$ & $8,80 \pm 24,70$ & $*$ \\
$16-20$ & $169,36^{\mathrm{a}} \pm 86,30$ & $31,48^{\mathrm{b}} \pm 27,98$ & $*$ \\
$16-21$ & $273,32^{\mathrm{a}} \pm 139,41$ & $76,24^{\mathrm{b}} \pm 35,43$ & $*$ \\
$16-22$ & $412,92^{\mathrm{a}} \pm 231,05$ & $162,40^{\mathrm{b}} \pm 64,58$ & $*$ \\
$16-23$ & $597,48^{\mathrm{a}} \pm 284,12$ & $282,72^{\mathrm{b}} \pm 107,94$ & $*$ \\
$16-24$ & $814,12^{\mathrm{a}} \pm 330,16$ & $436,64^{\mathrm{b}} \pm 175,94$ & $*$ \\
$16-25$ & $1022,44^{\mathrm{a}} \pm 356,86$ & $618,24^{\mathrm{b}} \pm 210,55$ & $*$ \\
$16-26$ & $1225,60^{\mathrm{a}} \pm 373,62$ & $808,92^{\mathrm{b}} \pm 240,91$ & $*$ \\
$16-27$ & $1428,96^{\mathrm{a}} \pm 408,85$ & $1000,40^{\mathrm{b}} \pm 271,10$ & $*$ \\
$16-28$ & $1643,28^{\mathrm{a}} \pm 442,58$ & $1187,32^{\mathrm{b}} \pm 294,39$ & $*$ \\
\hline
\end{tabular}

Keterangan $: \mathrm{ns}=$ berbeda tidak nyata $),{ }^{*}=$ berbeda nyata

\section{Konversi ransum}

Konversi ransum ayam Ketarras dan ayam Arab sejak minggu ke 17-28 disajikan pada Tabel 10. Tabel 10. menunjukkan bahwa nilai konversi ransum pada minggu ke 17 sampai 20 pada masingmasing jenis ayam relatif lebih tinggi, untuk selanjutnya konversi ransum cenderung menurun sampai minggu ke 28 . Konversi ransum bernilai tinggi pada awal minggu karena $50 \%$ ayam belum mencapai dewasa kelamin sehingga produksi telur masih rendah. Hasil uji t menunjukkan bahwa konversi ransum berbeda nyata pada minggu ke 23 dan 24 sedangkan pada minggu lainnya tidak terdapat perbedaan yang signifikan antra kedua jenis ayam. Menurut Windawati (2014), semakin rendah konversi ransum adalah semakin baik karena hal itu berarti bahwa ternak lebih efisiensi dalam menggunakan ransum. Darmana (2002) menyatakan bahwa konversi ransum merupakan perbandingan jumlah ransum yang dikonsumsi dengan berat telur yang dihasilkan. Ukuran efisiensi pada ayam petelur dilihat berdasarkan jumlah produksi telur yang dihasilkan. Semakin rendah konversi ransum, maka efisiensi ternak mengubah ransum menjadi telur semakin tinggi. Arianto (2017), terdapat kecenderungan bahwa konversi ransum kumulatif ayam Arras lebih rendah dibandingkan ayam Arab, hal ini menunjukkan bahwa efisiensi ransum ayam Arras lebih baik dibandingkan Arab.

Tabel 10. Uji t konversi ransum pada minggu ke 17-28

\begin{tabular}{llll}
\hline $\begin{array}{l}\text { Akhir Minggu } \\
\text { Ke }\end{array}$ & P0 (Ayam Ketarras) & P1 (Ayam Arab) & Keterangan \\
\hline 17 & $9,75 \pm 4,28$ & - & - \\
18 & $9,80 \pm 3,59$ & $16,41 \pm-$ & - \\
19 & $7,47 \pm 3,94$ & $14,91 \pm 4,00$ & - \\
20 & $7,09 \pm 3,84$ & $13,48 \pm 6,19$ & $\mathrm{~ns}$ \\
21 & $6,03 \pm 3,61$ & $10,31 \pm 3,91$ & $\mathrm{~ns}$ \\
22 & $5,26 \pm 5,05$ & $8,42 \pm 3,56$ & $\mathrm{~ns}$ \\
23 & $3,71^{\mathrm{a}} \pm 3,36$ & $6,38^{\mathrm{b}} \pm 3,06$ & $*$ \\
24 & $3,10^{\mathrm{a}} \pm 1,34$ & $5,13^{\mathrm{b}} \pm 4,13$ & $*$ \\
25 & $3,85 \pm 2,74$ & $3,48 \pm 1,30$ & $\mathrm{~ns}$ \\
26 & $3,45 \pm 1,77$ & $3,22 \pm 0,90$ & $\mathrm{~ns}$ \\
27 & $2,99 \pm 1,09$ & $3,08 \pm 0,84$ & $\mathrm{~ns}$ \\
28 & $3,38 \pm 2,04$ & $3,99 \pm 2,53$ & $\mathrm{~ns}$ \\
\hline
\end{tabular}

Keterangan :ns = berbeda tidak nyata ), ${ }^{*}=$ berbeda nyata 
Tabel 11. Persentase (\%) warna telur.

\begin{tabular}{llll}
\hline Perlakuan & CT (coklat tua) & PC (putih coklat) & P (putih) \\
\hline & $\ldots \ldots \ldots \ldots \ldots \ldots \ldots \ldots \ldots \ldots \ldots \ldots \ldots \ldots \ldots \ldots \ldots \ldots \ldots \ldots \ldots \ldots$ & \\
P0 (Ayam Ketarras) & 4,77 & 92,65 & 2,58 \\
P1 (Ayam Arab) & 0,00 & 1,85 & 98,15 \\
\hline
\end{tabular}

\section{Warna kerabang telur.}

Jumlah telur serta persentase telur berdasarkan warna kerabang telur ayam sejak dewasa kelamin sampai umur 28 minggu ditampilkan pada Tabel 11.

Berdasarkan Tabel 13. terlihat bahwa 92,65\% warna kerabang telur ayam Ketarras berwarna putih kecoklatan seperti warna kerabang telur ayam Kampung, 4,77\% berwarna coklat seperti warna kerabang telur ayam Ras petelur dan $2,58 \%$ berwarna seperti warna kerabang telur ayam Arab. sedangkan warna kerabang telur ayam Arab 98,15\% berwarna putih dan $1,52 \%$ berwarna putih kecoklatan. Hal ini menunjukkan bahwa perbedaan genetik antara kedua jenis ayam berpengaruh terhadap warna kerabang telur ayam yang dihasilkan.

Menurut Arianto (2017) pada penelitiannya menjelaskan bahwa warna kerabang telur ayam Arras didominasi oleh warna coklat $(87,10 \%)$ sedangkan warna kerabang telur ayam Arab didominasi oleh warna putih $(63,95 \%)$.

Terlihat bahwa jika dibandingkan dengan ayam Arras sebagai tetuanya yang $87,10 \%$ warna kerabang telurnya coklat, ayam Ketarras mengalami perubahan dengan 92,65\% warna kerabang telurnya berwarna putih kecoklatan dengan warna kerabang coklat hanya $4,72 \%$.

\section{KESIMPULAN}

Penelitian ini dapat disimpulkan bahwa dewasa kelamin ayam Ketarras lebih cepat, dengan berat dewasa kelamin lebih ringan, berat telur pertama lebih berat, konsumsi ransum tidak berbeda nyata, produksi telur lebih tinggi serta konversi ransum lebih rendah dibandingkan ayam Arab, serta warna kerabang telur seperti warna kerabang telur ayam Kampung.

\section{DAFTAR PUSTAKA}

Ambarwati, N. 2016. Performans keturunan ayam Arab dengan ayam Ras petelur (ayam Arras) betina dan ayam Arab betina umur 12 minggu - dewasa kelamin. Skripsi. Jurusan Peternakan Fakultas Pertanian Universitas Bengkulu

Arianto, S. 2017. Performans Produktifitas telur ayam Arras dan ayam Arab umur 20 sampai 40 minggu. Skripsi. Jurusan Peternakan Fakultas Pertanian Universitas Bengkulu

Binawati, D. K. 2008. Pengaruh laserpunktur terhadap kualitas telur ayam Arab. Journal of Science 02 (01): 28-34.

Darmana, W. dan Sitanggang, M. 2002. Meningkatkan Produktivitas Ayam Arab Petelur. Agromedia Pustaka. Jakarta.

Hartadi. H. S., Reksohardiprojo dan AD. Tilman. 2005. Tabel Komposisi Pakan Untuk Indonesia. Cetakan ke IV. Universitas Gajah Mada

Hudson, B. P., R. J. Lien, and J. B. Hess. 2001. Effect of body weight uniformity and prepeak feeding program on broiler breeder hen performance. J. Appl. Poultry Res. 10: 24-32

Indra,G. K Achmanu, dan A. Nurgiartiningsih. 2013. Performans Produksi Ayam Arab (gallus turcicus) Berdasarkan Warna Bulu. Jurnal Ternak Tropika, 14 (1):8-14

Kholis, S. dan M. Sitanggang. 2002. Ayam Arab dan Poncin Petelur Unggul. PT. Agro Media Pustaka. Jakarta.

Natalia, H., D. Nista, Sunarto dan D. S. Yuni. 2005. Pengembangan ayam arab. Balai Pembibitan Ternak Unggul Sembawa. Palembang.

Nataamijaya. A. G., A. R. Setioko, B. Brahmantiyo dan K. Diwyanto. 2003. Performans dan karakteristik tiga galur ayam lokal (Pelung, Arab, dan Sentul). Prosiding Seminar Nasional Teknologi Peternakan dan Veteriner 2003.

National Research Council. 1994. Nutrient 
Requirement of Poultry. Ninth Resived Edition. Printing and Publishing National Academiy of Science. Washington.

Priono, D. 2003. Performans Ayam Ras Petelur Tipe Medium Periode Tiga Bulan Pertama Bertelur yang Diberi Ransum Dengan Kandungan Metionin Pada Berbagai Level. Skripsi. Fakultas Peternakan. Institut Pertanian Bogor.

PT.Japfa Comfeed, 2001, Ayam Petelur. https://rohmatfapertanian. wordpress. Com / pkl- skripsi/1 - pkl-nining - 2011- ttg - stud i- tatalaksana - pemeliharaan - ayam - petelur - fase - finisher/ di akses pada tanggal 26 Februari 2017.
Singh, R., K. M. Cheng, and F. G. Silversides. 2009. Production performance and egg quality of four strains of laying hens kept in conventional cages and floor pens. Poult. Sci. 88: 256-264.

Sodak, J. F. 2011. Karakteristik fisik dan kimia telur ayam arabpada dua peternakan diKabupaten Tulungagung, JawaTimur. Skripsi. Institut Pertanian Bogor.

Windawati, A. 2014. Pengaruh Imbangan Energi-Protein Terhadap Performan Ayam Arab. Skripsi. Universitas Hasanuddin. Makasar. 